ISSN 1997-5902

\title{
Effect of selected essential oil plants on bacterial wilt disease development in potatoes
}

\author{
${ }^{1}$ Oboo H., ${ }^{1}$ Muia AW and ${ }^{2}$ Kinyua ZM \\ 1 Egerton University Njoro, P.O Box, 536 -20115, Egerton, Kenya \\ 2. National Agricultural Research Laboratories, P. O Box, 14733-00800, Nairobi, Kenya Corresponding author: \\ oboohenry@gmail.com

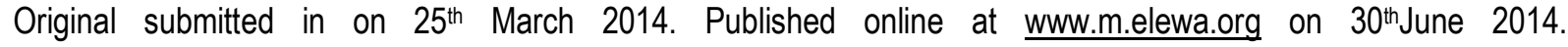 \\ http://dx.doi.org/10.4314/jab.v78i1.2
}

\begin{abstract}
Objective: Bacterial wilt disease caused by Ralstonia solanacearum is a major constrain to production of potatoes (Solanum tuberosum). Control of bacterial wilt is very difficult as there are no effective curative chemicals. This study was aimed at investigating the potential roles of essential oil plants in control of the disease.

Methodology and Result: The plants used included: Lippie javanica (Sage brush), Ocimum suave (Cambodia) and Tarchonanthus camphorates (Camphor brush).Experiments were conducted with potatoes grown in greenhouse condition. Freshly harvested leaves, stems and flowers from $L$. javanica, $O$. suave and $T$. camphorates were chopped into small portions that were soaked in water for one hour then applied in the inoculated experimental plots. Each plot was planted with disease-free potato tubers and disease development observed and recorded for a period of two months. Plots treated with $T$. camphorates had significantly low bacterial wilt incidence $(P<0.05)$ having been reduced by more than $90 \%$. Treatment with the other two plants, 0 . suave and $L$. javanica reduced the disease by $38 \%$ and $21 \%$ respectively and were not significantly different from untreated plots.

Conclusion and Application of Results: This finding shows that use of essential oils isa potential approach to bacterial wilt disease management. It can be concluded that essential oils plants possess antibacterial activity that is effective in control of $R$. solanacearum. Application of these essential oils can volatilize with increase of temperature. The application can be done by burying chopped essential oil plant parts in the soil during the time of land preparation just before planting. Further studies on the mode of action of these essential oils particularly those of $T$. comphrates in the control of $R$. solanacearum are suggested.
\end{abstract}

Key words: Essential oil plants, Potatoes, Ralstonia solanacearum, Wilt incidence

\section{INTRODUCTION}

Bacterial wilt (BW) also known as 'brown rot' is caused by Ralstonia solanacearum (Yabuuchi et al., 1995) formerly called Pseudomonas solanacearum. The disease is very difficult to control making it a major threat to production of solanaceous crops because this bacterium is a soil and seed-borne pathogen in potatoes with limited host resistance (Schaad et al., 2001). The primary factor contributing to wilting is probably blocking of vascular tissues of infected plants due to the high molecular mass of exopolysaccharide one (EPS1) produced by the pathogen (Elphinstone, 2005). Bacterial wilt causes 
economic problems worldwide leading to serious annual losses exceeding USD 950 million (Elphinstone, 2005). In Kenya, the pathogen has been reported at both low and higher altitudes (Nyangeri et al., 1984). Yield losses caused by bacterial wilt are estimated at $50-100 \%$ in traditional potato production areas in Kenya (Ajanga, 1993). Control of bacterial wilt is generally very difficult as there are no curative chemicals with breeding for resistance being only successful against race 1 of the pathogen in tropical crops like eggplant, tomato, peanut, pepper and to a very small extent potato in South America (van Elsas et al., 2005). Cultural measures have had only limited success (Lopez and Biosca, 2004). An emerging approach in disease management includes the use of plant extracts for their anti-microbial effects on pathogens. Essential oils from plants contain more than 200 compounds, consisting of volatile compounds such as terpenoids, aliphatic aldehydes, alcohols and esters (Dewick, 1997). Some volatile compounds derived from plants, like thymol (Thymus sp.) and palmarosa (Cymbopogon martinii) or other medicinal

\section{MATERIALS AND METHODS}

Collection of essential oil plants: Essential oil plants which had shown positive invitro antibacterial effects on $R$. solanacearum were used in this study Table 1 and Figure 1). The plants were collected from Egerton plants are antibacterial and have been widely used as general antiseptic, additive in cosmetics, food industry, or in the medical practice. Preliminary invitro as well as greenhouse experiments conducted with several plant essential oils with their components showed that some essential oils have significant efficacy against $R$. solanacearum and against several soil-borne fungi of tomato (Pradhanang et al., 2003). In agricultural studies, these compounds have broad-spectrum activities against nematodes, and insects. The potential of using plant essential oils in managing potato bacterial wilt disease has not been adequately investigated despite the finding that plant essential oils can manage bacterial wilt of tomato (Momol et al., 2005). The aim of this study was to develop management strategies against soil-borne $R$. solanacearum by recording disease incidences in potato plants grown in pathogen inoculated soils treated with plants commonly occurring as weeds in the wild in Kenya. The plants used in the study had been shown to possess invitro antibacterial effects on Ralstonia solanacearum .

University, Kenya Botanic Garden and identified with reference to taxonomic keys (Cowan, 1999)

Table 1: Essential oil plants tested for antimicrobial effects against $R$. solanacearum

\begin{tabular}{lcc}
\hline Common name & Scientific name & Family name \\
\hline Cambodia & Ocimum suave & Labiatae \\
Camphor brush & Tarchonanthus camphorates & Asteraceae \\
Sage brush & Lippie javanica & Verbenaceae \\
\hline
\end{tabular}

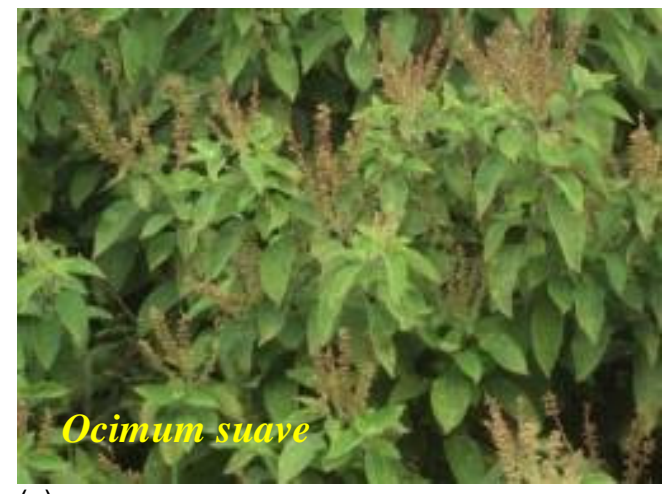

(a)

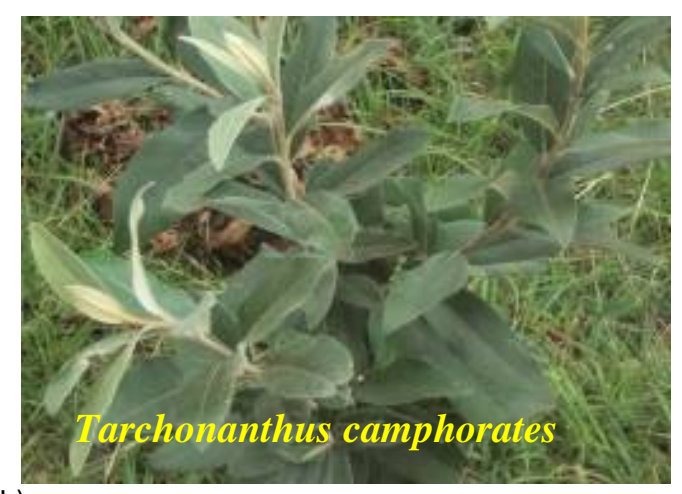

(b) 


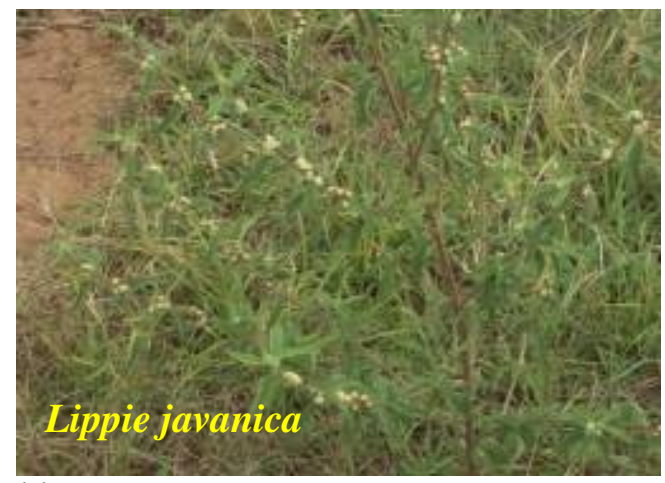

(c)

Figure 1: Essential oil plants used in the study (a) Ocimum suave; (b) Tarchonanthus camphorates; (c) Lippie javanica

All the plants were harvested by cutting the stem above the soil level to collect stems, leaves, flowers and the side branches. Harvesting was done in the mid-morning hours and packed in plastic sacks (each plant type per sack) that were used to ferry them to Kenya Agricultural Research Institute (KARI) in Nairobi where the study was done. The investigation was carried out in a greenhouse on raised beds measuring 1.5 meters by 2.0 meters and a depth of $30.0 \mathrm{~cm}$ between October and December 2011. Soil inoculation with pathogen: The soil on the beds were mixed with chicken manure at the rate of one wheelbarrow per bed followed by treatment with sodium methyl dithiocarbamate (Metham Sodium) at a dose rate of $100 \mathrm{ml} / \mathrm{m}^{2}(300 \mathrm{ml} / \mathrm{bed})$ as recommended by the manufacturer (FMC Foret, Spain). This was applied as a dilute suspension after topping up to a litre with water. The beds were then watered slightly and small furrows made at an interval of $15.0 \mathrm{~cm}$ along the length of each bed. The furrows were sprayed with metham sodium solution from a knapsack sprayer and covered with soil. Soil on the beds were levelled and then irrigated to saturation and left to stand for three weeks after which the soil in each bed was turned to vent excess volatility. The beds were inoculated by applying $R$. solanacearum suspension from infected potato tubers. Thus infected potato tubers (g) collected from farms in Meru County, Kenya were cut into small pieces then soaked in $25.0 \mathrm{ml}$ of tap water and the mixture allowed to stand for 1 hour and then thoroughly mixed again. The content was sieved into a sterile container to remove debris and mixed with a 24 hour old culture of $R$. solanacearum to make up a 2.0 litre solution that contained $1.0 \times 10^{7} \mathrm{CFU} / \mathrm{ml}$. This new mixture was transferred into knapsack sprayer. Small furrows were made again at an interval of $15.0 \mathrm{~cm}$ along the length of each bed and the inoculum sprayed at a rate of 1.0 liter/bed. The inoculated beds were watered and then left for three days (Figure 2).

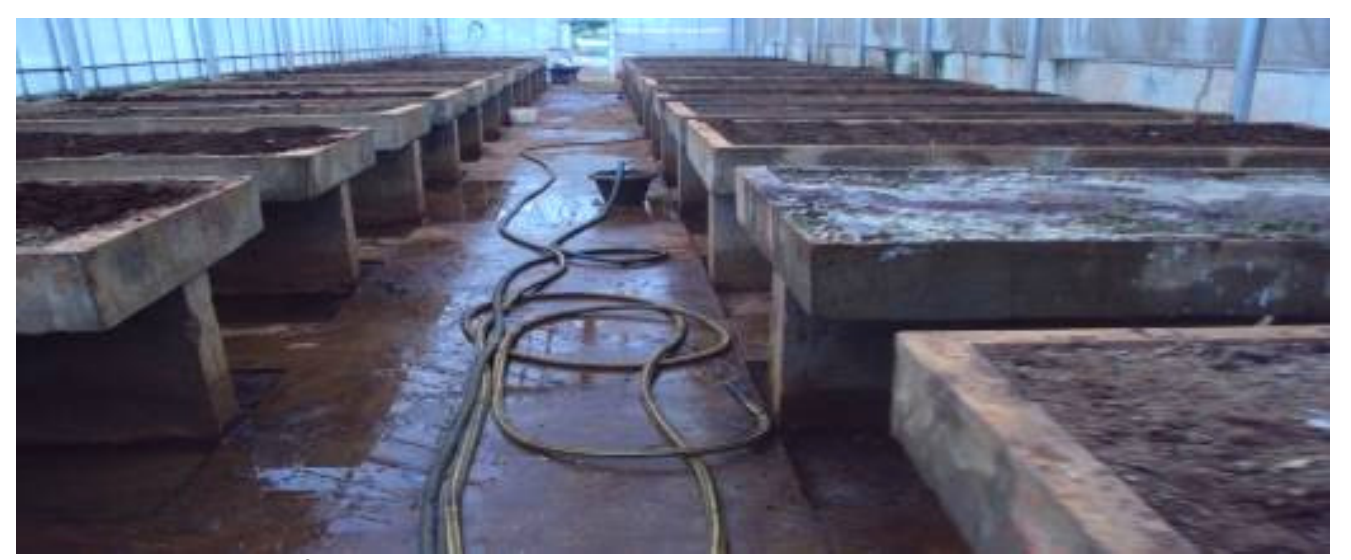

Figure 2: Watering of treated beds

Application of essential oil plants in test plots: Essential oil plants that had shown strong positive result in the in-vitro experiment were used as the treatments. In this case $2.0 \mathrm{~kg}$ of freshly harvested leaves stems and 

development in potatoes

flowers from $L$. javanica, $O$. suave and $T$. camphorates ware homogenized separately in 5.0 litres of tap water as per the method used by Ooshiro et al. (2004). The treatments were applied by turning the soil from one side of the bed followed by spreading of the plant parts to cover the soil and turning again to cover the whole bed as shown in (Figure 3).

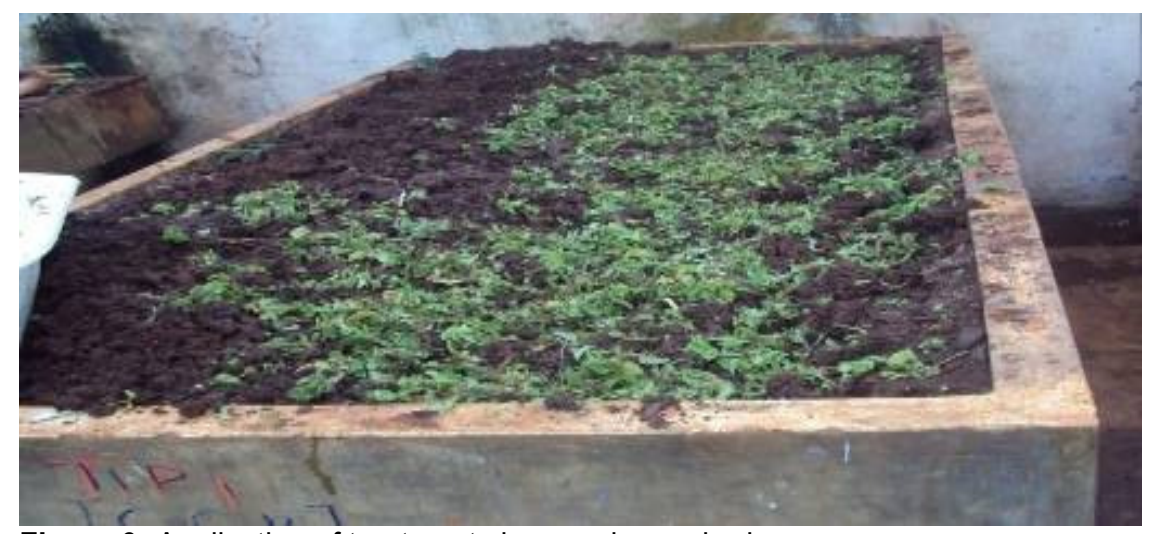

Figure 3: Application of treatments in greenhouse beds

Following the treatment, the soil in the beds was aseptically mixed thoroughly each day for three days to allow fumigation, and then left to stand for four days. The experiment was arranged in randomized complete block design (RCBD) with five replications (blocks) and three treatments (Essential oil plants, T1, T2 and T3 ( 0 . suave, $T$. camphorates and $L$. Javanica, respectively) along with two controls. One control had water used instead of extracts and this served as the negative control (T4). while the other was lacking both extracts and inocula and served as the positive control (T5) Seven days after treatment, each bed was planted with certified/diseasefree potato tubers (varity Tigoni) obtained from KARI Tigoni (National Potato Research Centre). Planting was done at a spacing of $45.0 \mathrm{~cm}$ between the rows and $30.0 \mathrm{~cm}$ between plants in a row giving a population of 15 plants per bed (Figure 3 and 4).

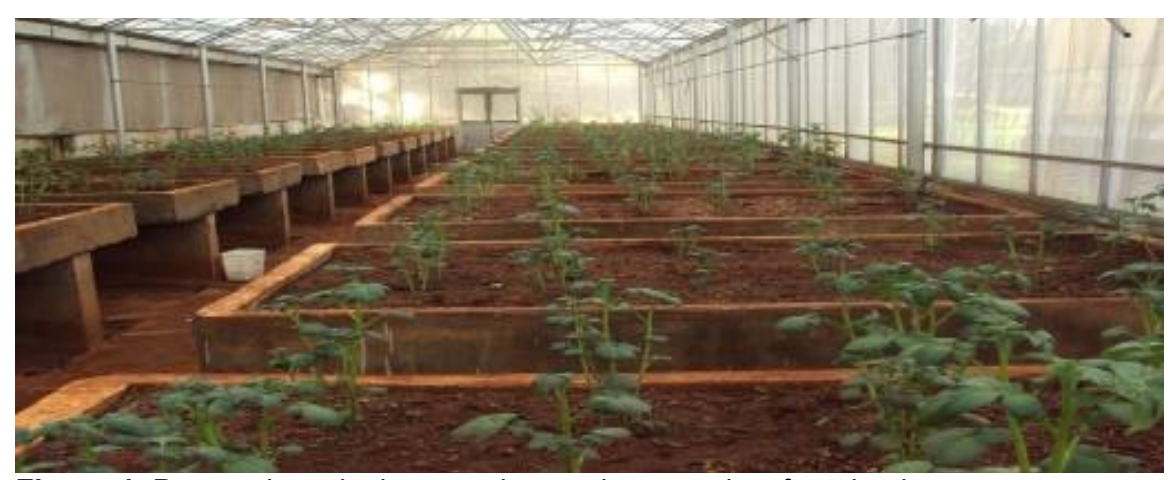

Figure 4: Potato plants in the greenhouse three weeks after planting

Disease incidence assessment: The plants were watered twice a week for a duration of three months and wilt incidence recorded starting 3 weeks after planting. Wilted plants were recorded for each treatment twice weekly for two months. Any abnormal symptom on leaves were observed and recorded. Wilt symptoms were observed in all the crops per plot and recorded for calculation of wilt incidence. Wilt incidence for all number of the crops (treatments) was expressed as a percentage of all the wilted plants over the total number of plants in the plot. 
Disease incidence $(\%)=\frac{\text { Number of wilted plants }}{\text { Total number of plants }} \times 100$

Statistical analysis was performed with the GenStat 12.1 (PC/Windows XP) while mean witt incidences were compared using Fisher's least significant difference (FLSD).

\section{RESULTS}

Disease progress in the greenhouse: Bacterial wilt symptoms started appearing at the end of the first month (30 days) following planting. From observations recorded, , 0 . suave (T1) had more wilting for the earlier parts of the second month (November 2011) with the highest at this time being an average of seven plants out of fifteen
$(46.67 \%)$ on the fifth day. This was followed by a decline for the rest of the time with an average record of three plants out of fifteen up to the ninth day. The next highest wilting was observed again in the early parts of the third month (December 2011) (Figure 5).

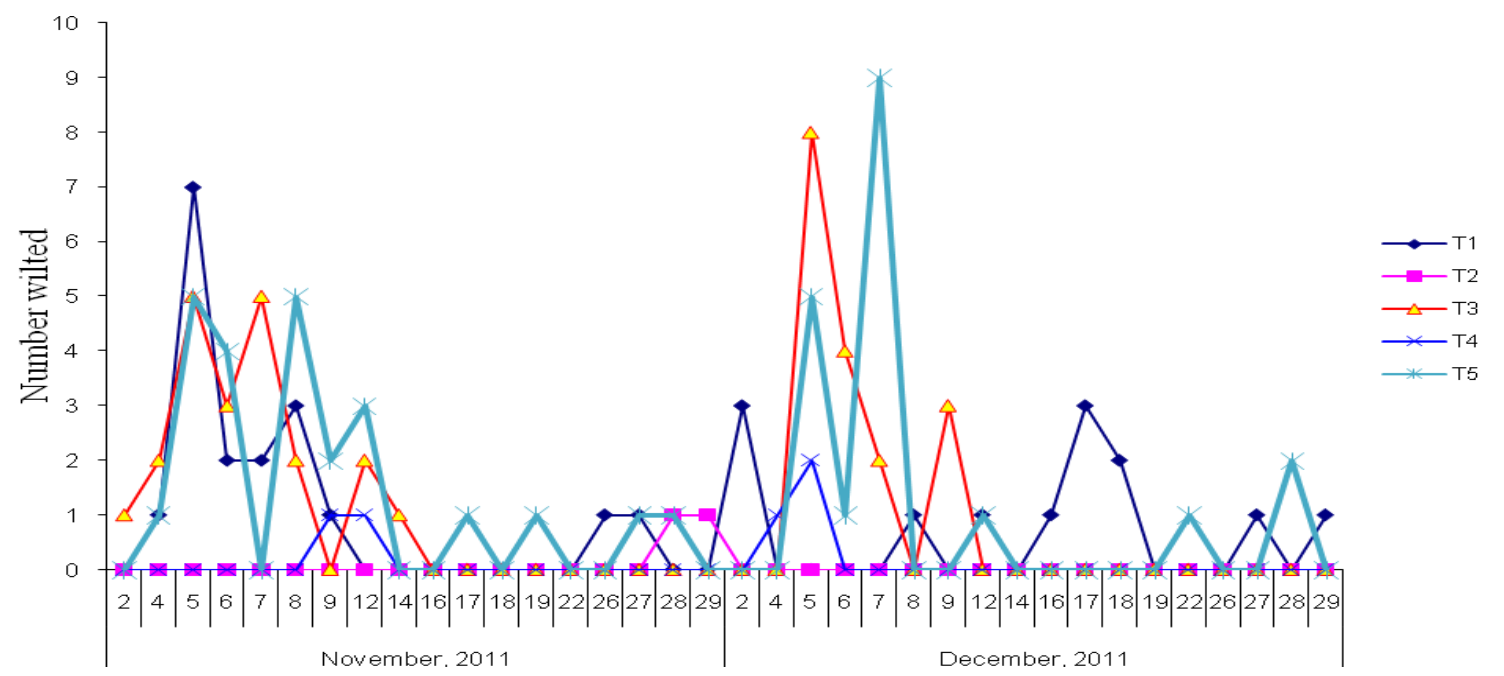

Figure 5: Disease progress in the greenhouse in comparison to the positive and negative control.

$\mathrm{T} 5=$ Positive control (has inoculum but not essential oil plant), $\mathrm{T} 4=$ Negative control (lacking inoculum and any essential oil plant), $\mathrm{T} 3=L$. Javanica, $\mathrm{T} 2=T$. camphorates $\mathrm{T} 1=0$. suave

T. camphorates treated plots (T2) had very low wilting plants observed in the second month (November 2011) with an average of one wilted plant in the last two days of this month. The negative control (T4) had wilt symptoms appearing on a few plants in comparison to the rest of the treatments towards the middle of November (second month after planting). The rest did not wilt till the early parts of December (third month after planting). L. javanica
(T3) exhibited increased wilt in the third month with an average of eight wilted plants out of fifteen (53.33\%) and average of five in the second month. In general, the unexpected incidences of wilt occurred in potatoes under the negative control probably due to soil-borne $R$. solanacearum. Some of the wilted and non-wilted potatoes in the greenhouse are shown in Figure 6. 
Oboo et al. J. Appl. Biosci. 2014. Effects of selected essential oil plants on bacterial wilt disease development in potatoes

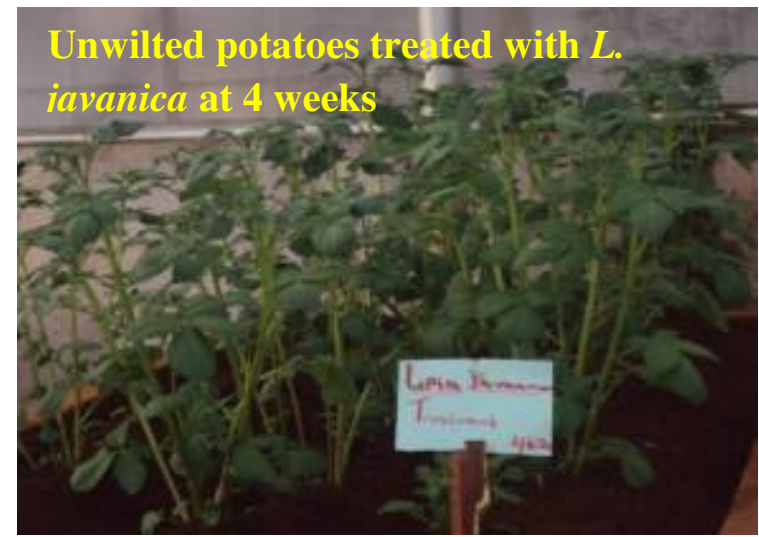

a

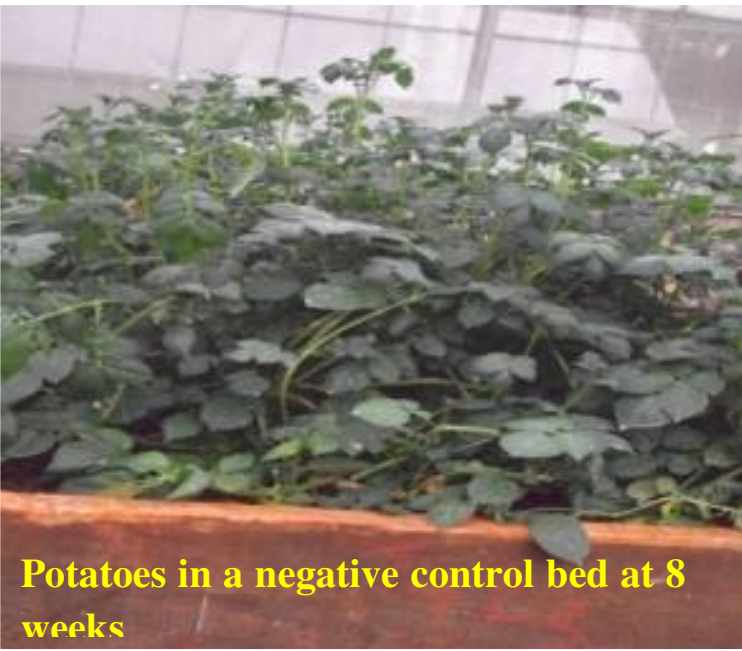

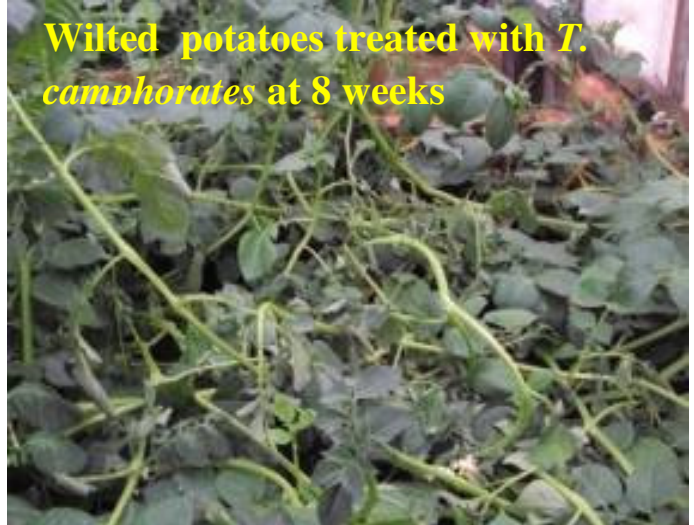

b

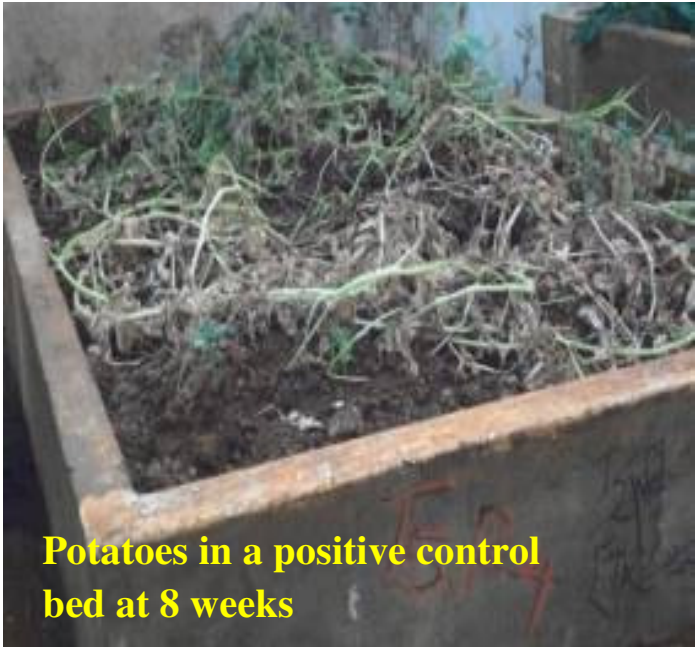

d

Figure 6: Crops in the greenhouse following treatment with plant extracts: (a) = Unwilted potato plants treated with $L$. javanica at 4 weeks $(b)=$ wilted potato plants treated with $T$. camphorates at 4 weeks, $(c)=$ Unwilted potato plants under negative control at 8 weeks,

(d) = Wilted potato plants under positive control at 8 weeks.

The trends observed above were, however, different in the beds that were treated with T5 (positive control) in which more than half the plants wilted in the plots treated during the second month and a maximum of five in the first month. O. suave (T1), L. javanica (T3) Positive control (T5) all had over $60 \%$ disease incidence. The most wilted beds were those that were treated with $L$. javanica (T3). By the second month, all the beds with $L$. javanica (T3) had wilted (Figure 7).

Wilt incidence: Disease incidences for the five treatments represented as means of wilted plants for the two months of observation are shown in (Figure 7 and Table 2). T. camphorates was significantly $(P<0.05)$ most effective in the control of potato wilt with potato plants showing only $6.7 \%$ wilt incidence 


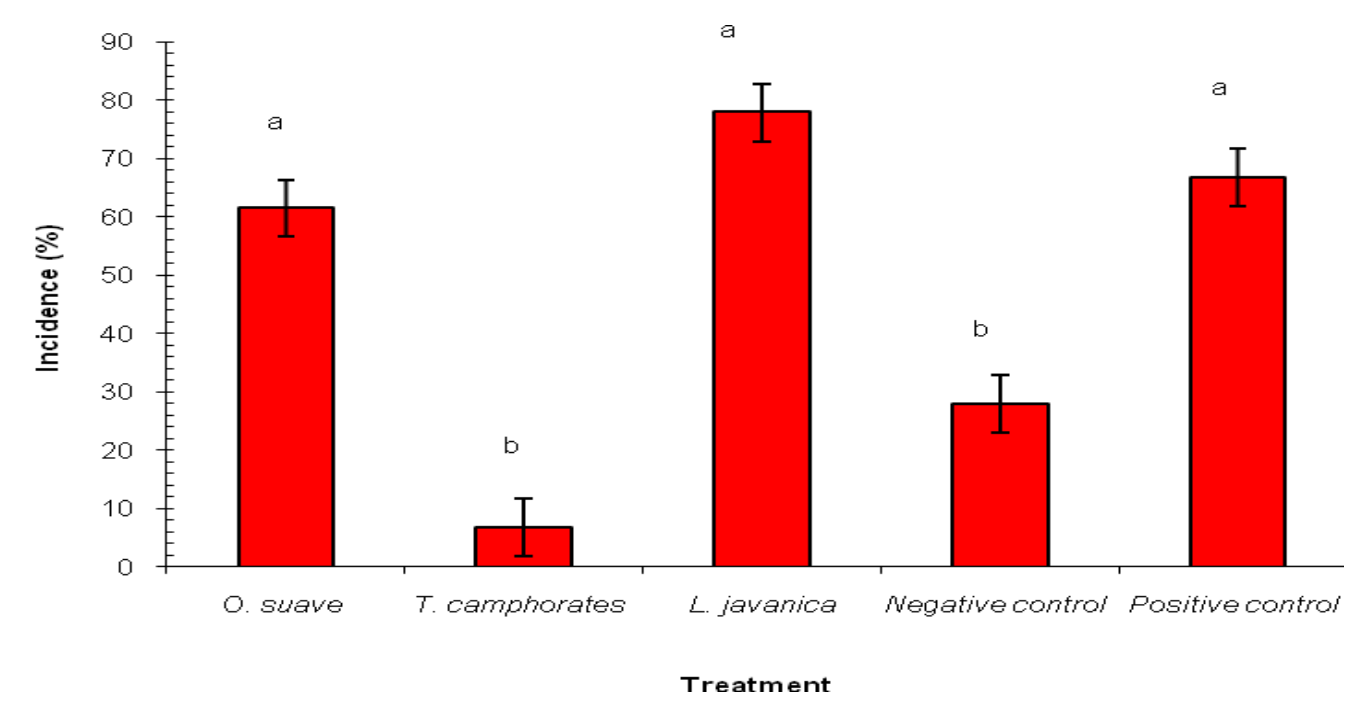

Figure 7: Disease incidence in the greenhouse experiment.

This confirmed that application of T. camphorates had strong antimicrobial property and was successful in control of bacterial wilt disease by reducing the wilt incidence by more than $90 \%$. The other two essential oil plant treatments including those by $O$. suave and $L$. javanica showed high disease $(>60 \%)$ and were not significantly different from each other and from the positive control. The positive control, these three treatments had high disease incidences with less than $40 \%$ disease reduction. L. javanica and 0 suave treatments had only $22 \%$ and $37 \%$ disease reduction respectively. The positive control consisting of beds inoculated with the pathogen but with no essential oil plant treatment also had high mean wilt incidence recorded. The unexpected wilt incidence in the negative control is probably due to soil borne pathogen not sensitive to the soil disinfectant methyl sodium. $L$. javanica (T3) exhibited a very high wilt incidence in the third month (December) with an average of eight wilted plants out of fifteen plants (53.33\%) and average of five in the second month. The positive control (T5) all had over $60 \%$ of the disease incidence with more wilt observed in December (third month after planting) (Table 2).

Table 2: Mean wilt incidence in the greenhouse

Code Treatment Mean incidence Mean differences

\begin{tabular}{llll} 
T3 & L. javanica & 77.90 & $\mathrm{a}$ \\
T5 & Positive control & 66.67 & $\mathrm{a}$ \\
T1 & O. suave & 61.52 & $\mathrm{a}$ \\
T4 & Negative control & 28.00 & $\mathrm{~b}$ \\
T2 & T. camphorates & 6.67 & $\mathrm{~b}$ \\
\hline
\end{tabular}

Means followed by different letters are statistically different at $P<0.05$ by Fisher's protected least significant difference test. T5 = Positive control (has inoculum but not essential oil plant), T4 = Negative control (lacking inoculum and any essential oil plant), $\mathrm{T} 3=L$. Javanica, $\mathrm{T} 2=T$. camphorates $\mathrm{T} 1=0$. suave.

\section{DISCUSSION}

Of all the three plants tested for disease control in the green house, $T$. camphorates was the best in the control of potato wilt as displayed by its effectiveness in wilt incidence reduction. This indicates that this plant can be applied directly in the soil before planting to control $R$. solanacearum. This method of application has also been 
found effective when using vegetative material of a leguminous plant, Cajanus cajan in greenhouse to reduce bacterial wilt incidences in tomatoes and potatoes (Cardoso et al., 2006). Biological control measures are becoming common in integrated pest management IPM) and integrated disease management (IDM). Integrative research strategies have been developed in trying to come up with plant species that can be intercropped with potato to reduce bacterial wilt incidences, coming up with positive beneficial microbes to counter soil pathogens, and incorporation of some parts of the plant to inhibit survival of pathogens (Ooshiro et al., 2004). It has been shown in certain studies that bacterial wilt in the greenhouse can be controlled almost $100 \%$ by incorporation of about $20 \%$ of fresh aerial parts of plants like Cajanus cajan (Cardoso et al., 2006). This is an encouragement for farmers if vegetative plant parts which are easy to apply can effectively controls bacterial wilt in the field to curb bacterial wilt in both tomatoes and potatoes. Furthermore plants such as T. camphorates are easily available in most forests in potato and tomato growing areas in Kenya and can be utilized in a similar manner. Ooshiro et al. (2004) also found out that the incorporation of young aerial leaves of some essential oil plants like Geranium carolinianum in the soil together with solarisation effectively counter act the microbial activities of $R$. solanacearum in the soil. The findings of this study showed that even though the extracts of $O$. suave, and $L$.

\section{CONCLUSION AND RECOMMENDATIONS}

It can be concluded that essential oils plants possess antibacterial activity that is effective in control of $R$. solanacearum. Application of these essential oils can volatilize with increase of temperature this the application can be done by burying chopped essential oil plant parts in the soil during the time of land preparation before planting. It is also worth noting that amount of essential oil released during chemical extraction from different

\section{ACKNOWLEDGEMENTS}

The authors are grateful to Association for Strengthening Agricultural Research in Eastern and Central Africa (ASARECA) which funded the research that enabled H.O finalize MSc thesis. Plant identification assistance given

\section{REFERENCES}

Ajanga, S. (1993). Status of bacterial wilt of potato in Kenya. In Hartman GL, Hayward AC (Eds). Bacterial wilt. ACIAR. 45: 338 -340.Canberra, Australia. javanica might have had an antibacterial effect on the pathogen in in-vitro test, the plants were not effective in green house reduction of potato wilt. There were no significance differences in wilt incidences between these essential oil plants and the positive control (pathogen plus no extract). These two essential oil plant seemingly had very little effect on reduction of wilt incidence contrary to the expectation based on the result from in-vitro experiment that exhibited significant effect on the growth of $R$. solanacearum by exhibiting antibacterial activity. This unexpected observation could be because of other factors that could have affected the interaction of the pathogen and the essential oils in the soil. This could range from release of essential oils from the plant materials, method of application of the essential oil plants to volatility of the essential oil in relation to the temperature of the greenhouse as was found out by Weiss (1997). Other researchers have suggested that suppression of soil towards bacterial wilt may be related to other factors such as $\mathrm{pH}$, organic matter content and microbial communities (Elsas et al., 2005). Some studies suggest that cropping of some of the essential oils and subsequent burying in the soil can reduce pest and other soil-borne diseases (Sandra, 2006). Periodic cropping and burying of aerial parts of these essential oil plants can significantly reduce loss of potatoes due to bacterial wilt disease caused by $R$. solanacearum.

essential oil plants may significantly differ from those released naturally by plants buried in the soil in greenhouse experiment. Such differences in the quantities could cause differences in invitro, greenhouse and field experiments. Following these findings, a further study on the mode of action of these essential oils particularly those of $T$. comphrates in the control of $R$. solanacearum is suggested.

by Dr. S.T. Kariuki of Egerton University, Biological Science Department is acknowledged. Mr. Joseph Kinoti of KARI is acknowledged for technical assistance.

Cardoso, S. C., Soares, A. C. F., Brito, A. d. S., Laranjeira, F. F., Ledo, C. A. S. and Santos, P. d. (2006). Control of tomato bacterial wilt through the incorporation of aerial part of pigeon 
pea and crotalaria to soil. Summa Phytopathologica. 32: 27-33.

Cowan, M.M. (1999). Plant products as antimicrobial agents. Clinical microbiology reviews. 12: 564582.

Dewick, P.M. (1997). Medicinal natural products: a biosynthetic approach. 2nd edition. United Kingdom: John Wiley and Sons. Pp 52.

Elphinstone, J. G. (2005). The current bacterial wilt situation: a global overview. pp 9-28 in Bacterial Wilt: The Disease and the Ralstonia solanacearum Species Complex. C. Allen, P. Prior, and A. C. Hayward, eds. American Phytopathological Society.

Lopez, M.M. and Biosca, E.G. (2004). Potato bacterial wilt management: new prospects for an old problem. In Allen C, Prior, P and Hayward. Bacterial Wilt Disease and the Ralstonia species complex. APS press, St. Paul, Minnesota, USA, pp. 205-224.

Momol, M.T., Olson, S.M., Pradhanang, P.M. and Jones, J.B. (2005). Evaluation of thymol as biofumigant for control of bacterial wilt of tomato under field conditions. Plant Disease, 89: 497-500.

Nyangeri, J.B., Gathuru, E.M. and Mukunya, D.M. (1984). Effect of latent infection on the spread of bacterial wilt of potatoes in Kenya. Tropical Pest Management, 30:163-165.

Ooshiro, A., Takaesu, K., Natsume, M., Taba, S., Nasu, K., Uehara, M. \& Muramoto, Y. (2004). Identification and use of a wild plant with antimicrobial activity against Ralstonia solanacearum, the cause of bacterial wilt of potato. Weed Biology and Management. 4: 187194.

Pradhanang, P.M., Momol, M.T., Olson, S.M. and Jones, J.B. (2003). Effects of plant essentialoils on Ralstonia solanacearum population density and bacterial wilt incidence in tomato. Plant disease. 87:423-427.

Sandra C.. (2006). Chemical constituents of lippia scaberrima. (Verbenaceae) Tshwane University of technology

Schaad, N.W., Jones, J.B. and Chun, W. (2001). Laboratory Guide for Identification of Plant Pathogenic Bacteria. $3^{\text {rd }}$ edition. American Phytopathological Society, Minnesota U.S.A. PP 151-160.

Schell, M.A. (2000). Control of virulence and pathogenicity genes of Ralstonia solanacearumby an elaborate sensory network. Annual Review Phytopathology. 38: 263-292.

Van Elsas, J.D. Van Overbeek, L.S., Bailey, M.J., Schönfeld, J. and Smalla, K. (2005). Fate of Ralstonia solanacearum biovar 2 as affected by conditions and soil treatments in temperate climate zones, The American Phytopathological Society. 65:39-49.

Weiss, E.A. (1997). Essential oil crops. New York: CAB International.Yabuuchi, E.,Kosako, Y., Yano,l., Hotta, H. and Nishiuchi, Y.(1995). Transfer of two Burkholderia and an Alcaligenes species to Ralstonia. Microbiolimmunoogyl. 39, 897-904. 